\title{
Linking teaching and research in the field of public health: the Bulgarian experience
}

\author{
Vinculando ensino e pesquisa na área de saúde pública: \\ a experiência búlgara
}

\author{
Maya Tcholakova ${ }^{1}$, Dobrinka Georgieva ${ }^{2}$, Stoyan Ivanov ${ }^{3}$
}

\begin{abstract}
We describe our perception of the link between teaching and research at South West University (SWU) in Blagoevgrad, Bulgaria. This analysis is based on a reflection of the existing curricula and research infrastructure at the Faculty of Public Health and Sports (FPHS) and a literature review of currently explored concepts and definitions connected to linking teaching and research. The research was conducted from April to December 2011 and was financed by the university. On the basis of our review we have proposed a framework for integrating teaching, research, and practice for the FPHS. We describe the key prerequisites for linking research and teaching and its clinical representation in Bachelor and Master's degree programs with the aim of encouraging critical thinking and clinical problem-solving skills in students and teachers.
\end{abstract}

Keywords: Public health; Speech-language pathology; Social work; Physical therapy modalities; Education; Teaching; Evidencebased practice

\section{INTRODUCTION}

In this article we describe our experience of introducing research-informed teaching (RIT) and evidence-based practice (EBP) into the undergraduate curriculum at South West University, in Bulgaria. We outline five distinct prerequisites for embedding RIT and EBP into the curriculum: one involving an undergraduate module (i.e., a course) and the other involving a clinical placement.

First, we provide a short overview of the curricula, programs, and research options at the Faculty of Public Health and Sports (FPHS). Next, we present a brief summary of selected and widely explored concepts of linking teaching and research. And finally, we propose a strategic framework for integrating teaching, research, and practice at FPHS based on a model developed at the School of Public Health and Clinical Sci-

The study was conducted at the Faculty of Public Health and Sports, South West University "Neofit Rilsky" - Blagoevgrad, Bulgaria.

(1) Department of Medical-Social Sciences, Faculty of Public Health and Sports, South West University "Neofit Rilsky" - Blagoevgrad, Bulgaria.

(2) Department of Logopedics, Faculty of Public Health and Sports, South West University "Neofit Rilsky" - Blagoevgrad, Bulgaria.

(3) Department of Sports and Kinesitherapy, Faculty of Public Health and Sports South West University "Neofit Rilsky" - Blagoevgrad, Bulgaria.

Correspondence address: Maya Tcholakova. Department of MedicoSocial Sciences, Faculty of Public Health and Sports, South West University. 66 Ivan Mihaylov Str., 2700, Blagoevgrad, Bulgaria. E-mail: maya_tcholakova@swu.bg

Received: 3/21/2012; Accepted: 6/4/2012 ences in the University of Central Lancashire (UCLAN), UK.

The Faculty of Public Health and Sports at the South West University "Neofit Rilsky", Bulgaria, is engaged in teaching students involved in the degree programs of Speech-Language Pathology (SLP), Kinesitherapy (Physiotherapy - PT)*, and Social Work (SW). The first two programs are located within the Public Health (PH) professional area. According to the European Union Statistics Classification of 1999 (ISCED 97: field of education and training; area 72: health and social sciences; professional direction 726: physiotherapy and rehabilitation), SLP and PT are considered health professions. The professional area of social service code 762 relates to Social Work and Consultations. As a member of the European Union, Bulgaria strictly adheres to these rules. In July 2009, the SWU Logopedics and Kinesitherapy programs successfully completed the official accreditation and evaluation procedures as part of the PH sciences specialties ${ }^{(1)}$. Social work received the highest evaluation under the same named professional field.

\section{CASE PRESENTATION}

The present research was conducted from April to December 2011 under a university financed project, "Educational and research quality management in the Faculty of Public Health

\footnotetext{
* The annual congress of the Bulgarian Association of Kinesitherapists and Rehabilitators held in 2011 decided to replace the term Kinesitherapy with the term Physiotherapy. However, the authors use the term Kinesitherapy as it is fixed in the documents explored.
} 
$\&$ Sports - Synchronization with the European and international standards". On this basis, we proposed and discussed a framework for integrating teaching, research, and practice for the Faculty.

The main purpose of the present theoretical research is to define and describe key prerequisites for linking research and teaching and its clinical representation in Bachelor and Master's degree programs, each aimed at encouraging critical thinking and clinical problem-solving skills in students and teachers.

In order to achieve the main purpose, we adopted three major tasks:

- a review of the curricula and programs in Logopedics, Kinesitherapy and Social Work along with an analysis of the prerequisites for research and teaching;

- a literature survey on the leading definitions and concepts of linking teaching and research;

- development of a vision for implementation of a RIT model at FPHS.

\section{DISCUSSION}

\section{Review of the Curricula in Logopedics, Kinesitherapy and Social Work at FPHS and analysis of the prerequisites for implementing the links between research and teaching}

\section{Context}

In Bulgaria, the European Credit Transfer System (ECTS) was first applied in 2004 (Ordinance number 21/30.09.2004 for the implementation of the System for Accumulation and Transfer of Credits in Higher Education Institutions). This document involves the three main degrees of higher education (HE): Bachelor, Master, and Doctor. The new SWU level curricula were based on and developed by internationally recognized specialists, education providers, and employers. For example, the first undergraduate Logopedics curriculum was developed within the framework of the World Bank project, "Modernization of Higher Education", in 2003/2004. As part of this project, the staff reviewed the academic and professional profile of a typical graduate in the field of $\mathrm{PH}$. The Logopedics program at SWU was the first and only accredited undergraduate program in the country in this professional field.
SWU has worked to organize its system of higher education in Logopedics, Kinesitherapy, and SW in accordance with the state normative documents, including:

- The Higher Education Act (State Gazette, No 61 from 9 $9^{\text {th }}$ of August 2011);

- Order RD-07-239 of 11.10.2007 on Classification of Educational Fields and the Rules for its implementation by the National Statistical Institute;

- Ordinance No. 125 of the Council of Ministers from 24 of June, 2002 for approval of a Classifier of Higher Education and the professional fields;

- Decree 162 as of July 23, 2002 on the State Requirements for Obtaining Higher Education in the degrees of "Bachelor", "Master", and "Specialist", and so forth.

Chart 1 shows the application of the national and international guidelines and standards to the Logopedics, Kinesitherapy and Social Work curricula.

The reflection process was facilitated by the involvement of SWU staff in the European Union project, "Network for Tuning Standards and Quality of Education programmes for Speech and Language Therapists in Europe" (Project number: 177075-LLP-1-2010-1-FR-ERASMUS-ENWA). The goal was to produce an overview and guidelines on how to design undergraduate and graduate program in Logopedics with integrated mobility. The National Society of Logopedists (NSL) in Bulgaria should establish its own standards for educating students, combining academic and clinical knowledge, as well as creating continuing education guidelines. In order to meet the revised 2010 IALP guidelines for initial education in Logopedics, a reevaluation and amendments are strongly recommended.

Logopedic student training is provided by the Department of Logopedics - the first and only such department in the country. The general research priorities are primarily directed to evidence-based practice in communication disorders especially fluency and voice disorders.

The Logopedics curriculum is a balanced program with five modules: 1) language; 2) behavior; 3) biomedical sciences; 4) ethical issues; and 5) specific communication disorders, such as: developmental and acquired speech disorders, voice and resonance disorders, fluency disorders, swallowing disorders, and reading and writing disorders. The Logopedics program provides practical experience for students by examining cases

Chart 1. Standards for curricula development in Logopedics, Kinesitherapy and SW specialties at South West University, Bulgaria

\begin{tabular}{|lll|}
\hline Logopedics & Kinesitherapy & Social Work \\
\hline $\begin{array}{l}\text { Revised IALP education guidelines for initial } \\
\text { education in SLP (2010) }\end{array}$ & $\begin{array}{l}\text { European Core standards of Physiotherapy } \\
\text { practice of the WCPT }\end{array}$ & $\begin{array}{l}\text { Global Standards for Social Work Education } \\
\text { and Training adopted by IASSW and IFSW } \\
\text { (2004) }\end{array}$ \\
\hline CPLOL guidelines (1998) & $\begin{array}{l}\text { Bulgarian Association of Kinesitherapists and } \\
\text { Rehabilitators }\end{array}$ & $\begin{array}{l}\text { Former state requirements for obtaining a } \\
\text { degree in Social Work (abolished in 2002) }\end{array}$ \\
\hline No national level standards & $\begin{array}{l}\text { Ordinance for the state requirements of } \\
\text { obtaining of the higher education on the } \\
\text { bachelor's degree of the Kinesitherapy as of } \\
\text { April, 27th, 1999) } \\
\text { Ordinance No } 4 \text { as of April 6, 2006 of the } \\
\text { Ministry of Health }\end{array}$ \\
\hline
\end{tabular}


of communication or oral disorders secondary to at least some of the following: hearing impairment; cerebral palsy and other neuromotor impairment, language learning impairment and disability, behavior and emotional disabilities, psychiatric disabilities, etc. (see revised IALP education guidelines, 2010). The integration of knowledge, skills, and competence underlies each course's content.

The speech language pathologist requires both scientific knowledge and clinical competence in order to provide optimal levels of client care. This role is stated in the following:

- Prevention - public awareness of communication disorders; early identification;

- Assessment - skills to apply objective testing and observation, and consultations with the client and his/her family members;

- Intervention - the goals are based on client assessment and may include early intervention, rehabilitation, counseling, consultation and participation in management by team. Evidence-based therapy application is strongly recommen$\operatorname{ded}^{(2)}$.

Supervised practical work in Logopedics should be aimed at developing general assessment and therapy skills in students and at fostering interactive communication skills.

The Kinesitherapy curriculum comprises fundamental knowledge of social and behavioural sciences, on the one hand, and medical and biological sciences on the other. In addition, it focuses on integrating knowledge about pathological processes and functional impairments with the therapeutic approach and kinesitherapy in particular. The newly qualified specialist in Kinesitherapy should be able to: conduct functional testing and assessment, perform functional and diagnostic activities, apply the theory and methods of kinesitherapy to various diseases and conditions, and provide health information and advice.

These modules aim to train students to:

- carry out up-to-date research and participate in various

Bulgarian, European and international programs;

- evaluate, test and train athletes from various sport;

- prepare effective training programs and keep accurate records related to the effects of sport training;

- practice effective rehabilitation using eccentric, concentric, and isometric contractions of skeletal muscles and open and closed kinetic chains after surgery or immobilization, etc.;

- engage in collaborative research programmes with Bulgarian and foreign scientists.

Taken together, this will ensure the quality education of postgraduate and graduate students.

The Social Work curriculum provides fundamental and integrated knowledge from the social, psychological, legal, and medical sciences needed to develop skills for: communicating with people of various ages and from various social and ethnocultural communities; engaging in individual and group work; conducting social surveys; developing social prognoses; and resolving concrete social problems. The typical graduates in the field of Social Work should be skilled in applying knowledge in his/her professional practice in the domains of social service, assistance, education, and prevention. They also should be able to use and apply the legislative and normative documents in the areas of social care, service, and assistance.
The research priorities of the Department of MedicalSocial Sciences' academic team (who are responsible for the education of students in Social Work) are broadly interdisciplinary and directed towards Public Health and Social Sciences. These priorities include: medical-social problems of at-risk groups, health promotion, current social and health policies, child abuse and neglect, unemployment, psychosocial rehabilitation, etc.

We have identified the following five prerequisites for linking research and teaching at FPHS:

- availability of appropriate normative basis at the European, national and university levels; availability of accredited degree programs in the professional field of Public Health with over 25 years of history;

- availability of highly qualified academic staff;

- accumulated experience of participation in educational and research projects, including the area of EBP;

- availability of educational and research infrastructure.

It is our opinion that the above prerequisites will favour the introduction of the RIT model described further below.

There is a general legislative and normative framework to build on with respect to linking teaching and research. The national level context includes the National Roadmap of Research Infrastructure Development (2010), the National Research Strategy, the National Strategy for the Development of the Scientific Research (2009-2020), etc. In accordance with the spirit and requirements of the Higher Education Act, conditions must be ensured for the development of research, culture, and innovations. This is in addition to the preparation of specialists who are able to develop and apply scientific knowledge in various fields and the qualification of experts.

The institutional strategies adopted so far are directed to developing and strengthening the scientific research capacity, attracting greater external funding, and increasing the academic reputation of the program.

As for the level of the faculty, the academic programs of the three specialties meet the current national, European, and world standards. In addition, the programs have received a positive evaluation by the National Agency for Accreditation and Evaluation. They were developed within the framework of international educational projects and were guided by the advice of international consultants.

The above programs are staffed by highly qualified academicians with research orientation and strong publication activities. There is an accumulated experience in the field of international exchange programs such as Erasmus and Fulbright, as well as in strictly research oriented programs such as Cooperation in Science and Technology (COST) and the $7^{\text {th }}$ European Union Framework program.

A research infrastructure has been built in compliance with the requirements for applied research in the fields of SLP, SW and Kinesitherapy. It should, however, be broadened and modernized in the coming decade according to the approved Roadmap of the SWU research infrastructure (2008).

The University Stuttering Research Center (USRC) is a unique structural unit specializing in evidence-based assessment and treatment of stutters. The three fundamental approaches of the USRC are: therapeutical, educational, 
and applied research. The center works in close relation and collaboration with internationally recognized scientists (http:// usrc.swu.bg).

The Logopedics center, operating within the structure of the FPHS, also offers speech therapy services for individuals with various communication disorders (http://www.logopedics. swu.bg).

The main purpose of the Center of Mental Health (founded in 2002) is to integrate the knowledge and skills of the specialists in mental health. It also provides opportunities for undergraduate and postgraduate students to participate in scientific research activities, consultations, and education (in the form of workshops, trainings, seminars, etc.). As a result of a joint project between the Centre of Mental Health and the Global Initiative in Psychiatry, the Information Centre for Mental Health was founded in 2005 and established the project, "Piloting community-based services in a Bulgarian setting".

The established Center for Functional Research in Sports and Kinesitherapy provides modules such as: isokinetic dynamometry, kinesiologic electromyography, polyphysiographic registrations; biochemical estimation of lactate and glucose levels in the blood, spiroergometry, and antropometry.

The recently equipped and modernized research laboratories and centers at South West University additionally provide unique opportunities for contemporary integrated research in both rehabilitation and sport science. Special research priorities in the Department of Sports and Kinesitherapy include: prophylaxis, therapy and rehabilitation, health promotion, maintenance and recuperation, functional research in kinesitherapy and sport, and evaluation of the work capacity of healthy persons.

The modern research infrastructure allows for participation in research projects financed by the university, national, and European sources. Such projects are currently being developed by FPHS researchers within the framework of the existing research centers. In addition, the application of international innovation experience is provided through cooperation and collaboration with prominent international scientists/researchers.

Student research activities are strongly encouraged and follow specific rules within the general Rules for Providing Research Activities at SWU adopted in 2009. Conditions for linking education, research and practice are in place at the faculty level.

\section{Specific evidence-based practice and research-informed teaching projects}

The revised IALP guidelines (2010) developed by the educational committee state: "Academics on the programs should be active in research in speech-language pathology and/or its supporting disciplines, so as to stimulate interest in research and to keep academics and students up to date with current developments in these fields, e.g. with singlecase studies of behavioral analysis in clinical assessment. All programs should include a research project to foster a research-oriented (evidence-based) approach to clinical work, and to assist the student in the critical examination of research in the field."(2:215).
Following this standard, SWU research staff developed the project, "Evidence-based practice in fluency and voice disorders" (DTK 02/33 for period 2009-2012) which is funded by the Bulgarian National Science Fund. The main goal of the project is to examine the effectiveness of speech therapy interventions for clients with fluency and voice disorders with respect to the outcomes obtained. This new Evidence-Based Practice paradigm is virtually unknown among Bulgarian logopedists. This newly emerged health care concept emphasizes the importance of research evidence in guiding clinical decision making.

\section{Literature survey on leading definitions and concepts of linking teaching and research - a short review}

\section{Context}

Linking teaching with research is among the most important issues facing higher education in contemporary Bulgarian society. Until recently, research institutions and teaching-only institutions have been separated. The primary mission of teaching at universities had little to do with the "pure" research, at least at the undergraduate level. Of course, efforts to involve students in research and to provide research-informed teaching in its modern understanding existed, however it wasn't a strategic vision or a mission goal of universities in general. Nevertheless, the demands of the $21^{\text {st }}$ century knowledge society have brought about changes in the traditional view concerning the role of universities in the rapidly developing competitive circumstances.

Our primary interest was to find out how the links between teaching and research should be addressed in Bulgarian higher education, particularly at SWU; more specifically, we focused on the FPHS. In order to do this, we surveyed the literature for the leading and most influential concepts and definitions of research-informed teaching. We performed a systematic review of journal articles and other publications available on the Internet using Academic Search Complete to survey the EBSCO database for articles in scholarly (peer reviewed) journals. Using a specific set of search words, we identified 364 articles from the period of 1990 to 2011. We grouped the results as follows:

- Research Informed Teaching - 6 (1998-2010);

- Linking Research and Teaching - 254 (1998-2011);

- Research Teaching Nexus - 33 (1994-2011);

- Integration of Teaching, Research and Practice - 18 (19962011);

- Research Teaching Scholarship - 53 (1994-2010).

Additionally, we identified a great number of papers, booklets and other internet sources using Google science search. In total, we reviewed around 400 written sources resulting in 41 units of analysis. Of these, 18 met the required four criteria for inclusion: relevance to the present research purposes; relevance to the Bulgarian HE context; number of citations; and most recent publications. Short notes and a brief summary of the selected works organized according to the aforementioned criteria are provided below.

There is a systematization of the link between research and teaching according to five perspectives: particular discipline 
perspective; institutional perspective; academic staff perspective; students' perspective; and different national contexts perspective $^{(3)}$.

Some authors assert that connecting student learning to research can be highly beneficial for both staff and students. Research active staff may find new stimulation and creativity from undergraduate students, while student can benefit from integrating research into their learning ${ }^{(4)}$.

Others argue that strategies linking R\&T depend on various factors such as the unit of assessment (individual, departmental, institutional); level of competence (teaching or research); stakeholder perspectives (academic staff, students, administrators, funding bodies); and cultural factors (different countries, international dimensions). Among these, the most influencial factors, as identified in several studies, are the type of department, discipline, and level of study ${ }^{(5)}$.

Factors influencing variability in research-teaching links may be discipline, national context, academic context (institutional type, and departmental practices), and individual characteristics (motivations, skills and dispositions). Each of these influences the disciplinary effects on teaching and research relationships ${ }^{(6)}$.

One of the main protagonists in the area of research-informed teaching is Griffiths. He proposed the famous typology of linking teaching and research where the teaching can be: 1) research-led, when students learn about research findings; the curriculum is structured around subject content, and the content selected is directly based on the specialized research interests of the teaching staff; 2) research-oriented, where students learn about the research process; the curriculum places emphasis as much on understanding the processes by which knowledge is produced in the field as on learning the codified knowledge that has been achieved; 3) research-based, when students learn as researchers; the curriculum is largely designed around inquiry-based activities, rather than on the acquisition of subject content; the experiences of staff in processes of inquiry are highly integrated into the student learning activities; and 4) research-informed, which draws consciously on systematic inquiry into the teaching and learning process itself $^{(7)}$.

Another categorization based on the three components provided by Griffiths suggests "research-tutored" teaching and the popular four axes' diagram where four quadrants are formed depending on whether students are participants or audience, and whether the focus is on the research content or the research processes ${ }^{(8)}$.

In addition, the Guide to the Research Evidence on Teaching-Research Relations focuses on the relationships between research and teaching by exploring how disciplinebased research impacts teaching practice and student learning ${ }^{(9)}$. Jenkins and Healey elaborate on a number of institutional strategies to link research and teaching at various universities across several countries ${ }^{(10)}$. The value of the research-teaching link is discussed in three perspectives: 1) experientally: a process which benefits teachers and students; 2) conceptually: social needs, development and communication of knowledge; and 3) operationally: potential reciprocity of teaching and research as learning activities ${ }^{(11)}$.

There is also a focus on various concepts, such as the research-teaching nexus and research-informed teaching, by offering a redefinition of research-informed teaching including academic programme research and pedagogic research and the scholarship of learning and teaching. A framework of the research-teaching complex is being introduced which the author hopes will aid developments in this area and contribute to further discussion and debate ${ }^{(12)}$.

We found data from a study on the perceptions of academic staff with respect to the nexus among research, teaching, scholarship, and consultancy in addressing the re-conceptualising of nexus concept ${ }^{(13)}$.

The existing diversity in the categorizations of the link between teaching and research is discussed exploring the concepts of the leading researchers in the above area. The authors provide empirical data on how academics in the humanities ideally perceive the research-teaching nexus. They identified five profiles in shaping the research-teaching nexus with each having its own advantages for teachers and students ${ }^{(14)}$.

On the basis of the survey, we take advantage of the work on institutional strategies to link teaching and research and more specifically of the hope that the booklet will help "to reflect on what you already have in place in your institution and give you ideas and strategies with which to go forward"(10:53).

\section{Development of a vision about the implementation of a RIT model at FPHS}

In 2011, the project, "Educational and Research Quality Management in the Faculty of Public Health and Sports - Synchronization with the European and International Standards" was funded by South West University under Decree No. 9 (internal university financing). After analyzing the research evidence mentioned above, we decided to elaborate on the best practices existing at leading European universities in the field of Public Health. Under this project, we explored the University of Central Lancashire's model of integrating teaching, research, and knowledge transfer in the School of Public Health and Clinical Sciences in detail. The framework described by the five editors includes the following four categories:

- Research-led: where teaching is focused on imparting information to students about research findings pertinent to the specialty;

- Research-oriented: which accents knowledge construction; - Research-based: which focused on inquiry-based learning;

- Research-tutored: which pays attention to writing and discussing papers, course work etc. ${ }^{(15)}$.

Furthermore, integration between research, teaching, and practice at UCLAN is presented in a four-component framework including integration between research and teaching (interaction between students, academic staff, and researchers), development of students' critical thinking (students as researchers), linkage between research and practice (students as brokers of knowledge), and evaluation and monitoring of learning content ${ }^{(15)}$.

Based on the above framework, we developed a strategic vision for strengthening the links among teaching, research, and practice at the FPHS. The reflection process gives evidence that the Faculty of Public Health and Sports at South West Univer- 
sity can accept and further develop this model. As a result of the project, we developed a conception for the structural and functional development of the Public Health and Sports' Faculty in a multifunctional campus through integration of teaching, research and therapy and introduced it to the academic and research community. According to the above conception, the multifunctional campus will ensure improvement in linking teaching, research, and evidence-based practice, and it will create conditions for involving students from the very first year of their undergraduate studies in the three programs.

\section{FINAL COMMENTS}

To sum up, the experience with the RIT at SWU is still far from being completely successful in implementing the necessary links between teaching and research. However, the commitments at both the national and institutional levels, as well as the initial steps in providing a framework for combining teaching, research, and practice will hopefully enhance this process at least at the level of the Faculty of Public Health and Sports. There is still a need for further research, strong will, and the implementation of pragmatic measures in order to bring about the realization of the conception.

\section{ACKNOWLEDGMENTS}

The authors acknowledge the help of Dr. William Clark for suggestions and assistance in writing this article in English.

\title{
RESUMO
}

\begin{abstract}
O texto descreve nossa percepção do vínculo entre ensino e pesquisa na South West University (SWU) em Blagoevgrad, Bulgaria. Essa análise é baseada em uma reflexão sobre o currículo e infraestrutura de pesquisa existentes na Faculdade de Saúde Pública e Esportes (Faculty of Public Health and Sports - FPHS) e em uma revisão da literatura referente aos conceitos e definições atualmente explorados na conexão entre ensino e pesquisa. A pesquisa foi conduzida entre abril e dezembro de 2011, e foi financiada pela universidade. Com base na revisão, foi feita umaa proposta para integração de ensino, pesquisa e prática na FPHS. São descritos os pré-requisitos essenciais para vincular ensino e pesquisa e sua representação clínica em programas de graduação e pós-graduação no nível de Mestrado, com o objetivo de incentivar o pensamento crítico e as habilidades de resolução de problemas clínicos em estudantes e docentes.
\end{abstract}

Descritores: Saúde pública; Patologia da fala e linguagem; Serviço social; Modalidades de fisioterapia; Educação; Ensino; Prática clínica baseada em evidências

\section{REFERENCES}

1. Georgieva D. Education of logopedists or speech-language pathologists in Bulgaria, Greece, Macedonia, Poland and Russia. Folia Phoniatr Logop. 2010;62(5):217-22.

2. International Association of Logopedics and Phoniatrics Education Committee. Revised IALP education guidelines (September 1, 2009): IALP Guidelines for initial education in speech-language pathology. Folia Phoniatr Logop. 2010;62(5):210-6.

3. Lucas L. Research and teaching work within university education departments: fragmentation or integration? Journal of Further and Higher Education. 2007;31(1):17-29.

4. Boyer Commission on Educating Undergraduates in the Research University. Commission on educating undergraduates in the research university. Reinventing undergraduate education: a blueprint for America's research universities. Stony Brook: State University of New York at Stony Brook. 1998. Available from: http://www.niu.edu/ engagedlearning/research/pdfs/Boyer_Report.pdf

5. Elton L. Research and teaching: conditions for a positive link. Teaching in Higher Education. 2001;6(1):43-56.

6. Colbeck CL. A cybernetic systems model of teaching and research production: impact of disciplinary differences. In: International Colloquium on Research and teaching: closing the divide? 2004 March 17-19; Winchester Hampshire, UK.

7. Griffiths R. Knowledge production and the research-teaching nexus: the case of the built environment disciplines. Studies in Higher Education. 2004;29(6):709-26.

8. Healey M. Linking research and teaching: exploring disciplinary spaces and the role of inquiry-based learning. In: Barnet R (editor). Reshaping the University: new relationships between research, scholarship and teaching. Maidenhead: McGraw-Hill/Open University Press. 2005. p. 30-42.

9. Jenkins A. A guide to the research evidence on teaching-research relations. The Higher Education Academy; 2004.

10. Jenkins A, Healey M. Institutional strategies to link teaching and research. York: The Higher Education Academy; 2005.

11. Jenkins A, Healey M, Zetter R. Linking teaching and research in disciplines and departments. York: The Higher Education Academy; 2007.

12. Haslett SK. Unpicking the links between research and teaching in Higher Education. Newport CELT Journal. 2009;2:1-4.

13. Grant K, Wakelin SJ. Re-conceptualising the concept of a nexus? A survey of 12 Scottish IS/IM academics' perceptions of a nexus between teaching, research, scholarship and consultancy. Teaching in Higher Education. 2009;14(2):133-46.

14. Visser-Wijnveen GJ, Van Driel JH, Van der Rijst RM, Verloop N, Visser A. The ideal research-teaching nexus in the eyes of academics: building profiles. Higher Education Research \& Development. 2010;29(2):195210.

15. Day P, Downe S, Milston AM, Roddam H, Hart A (Editors). Impact. Linking teaching and research. School of Public Health and Clinical Sciences. Preston, Lancashire: Centre for Research-Informed Teaching, University of Central Lancashire; 2009. Available from: http://www. uclan.ac.uk/information/services/ldu/research/files/IMPACT-HealthFINAL-16-6-09.pdf 